\title{
Anti-oxidative Potential Survival of E. crassipes Under Oxidative Stress
}

\author{
Sangya S. Bais ${ }^{* 1}$, Lawrence K. ${ }^{2}$, Priya S. ${ }^{3}$ and Gavhale V. ${ }^{4}$ \\ ${ }^{1 *}$ Dept. of Biochemistry, SDKS Dental College and Hospital, Nagpur, India \\ ${ }^{2}$ Dept. of Biochemistry and Biochemical Engineering, SHUATS, Prayagraj, India \\ ${ }^{3}$ Dept. of Microbiology, SDKS Dental College and Hospital, Nagpur, India \\ ${ }^{4}$ Dept. of Biochemistry, SDKS Dental College and Hospital, Nagpur, India \\ *Corresponding Author: - bais.sangyasingh@gmail.com, Tel.: 9453935355
}

Available online at: www.isroset.org

Received: 22/May/2019, Accepted: 09/Jun/2019, Online: 30/Jun/2019

\begin{abstract}
The present study evaluates the kinetic constants of enzymatic assays in crude extracts of roots and shoots of $E$. crassipes growing in wastewater bodies situated in the trans-Ganges/Yamuna regions of Allahabad. The increased kinetic constants in crude extracts of shoots and roots of E. crassipes showing the ability to protect plants from heavy metal induced oxidative stress by activating multi-defense mechanisms and for better growth in polluted environments. This study demonstrates the phytoremediation potential of E. crassipes for the removal of polluted effluents and their ability to survive under oxidative stress.
\end{abstract}

Keywords: Phytoremediation, kinetic constants, oxidative stress, wastewater, heavy metal, multi-defense mechanisms

\section{INTRODUCTION}

Water is an important substance on earth for the survival of living organism i.e. human, plants and animals. Speedy population growth and increasing use of water is likely to become an issue in near future due to limited sources of drinking water [1].

Water pollution is jeopardizing our health. Our drinkable water sources are finite. Less than 1 percent of the earth's freshwater is actually accessible. Challenges only increases by 2050, when global demand for freshwater is expected to be one-third greater by now. Municipal and industrial waste discharges contribute their fair share of toxins contaminating stream, river, lake, ocean, aquifer or other bodies of water, degrading the water quality [2].

Although nature possesses abundant capacity to deal with waste water and even pollution via macrophyte which possess a well-developed fibrous root system and large biomass and has been successfully used in wastewater treatment systems to improve water quality by reducing the levels of organic and inorganic nutrients and help in re-establishing and preserving biological, chemical and physical integrity of water. Conserved wastewater can be applied in the restoration of natural ecosystems, industries and for human consumption [3]. The term "phytoremediation" is derived from the Greek word $\varphi_{\text {vio }}$ (phyto) = plant and Latin word "remedium"= restoring balance, or remediation; involves justifying contaminant concentrations in polluted soils, water or air with naturally occurring plants that have ability to accumulate, crude oil, degrade metals, explosives, pesticides, solvents, , and its derivatives [4] and [5]. Eicchornia crassipes growing in wetlands and flooded fields, their roots play significant role in improving the physico-chemical properties of the wastewater [6], [7] and [8].

The study reports that the increased kinetic constants in crude extracts of shoots and roots of $E$. crassipes showing the ability to protect plants from heavy metal induced oxidative stress by activating multi-defense mechanisms and for better growth in polluted environments. This study demonstrates the phytoremediation potential of E. crassipes for the removal of polluted effluents and their ability to survive under oxidative stress.

\section{MATERIALS AND METHODS}

- Study area and Sampling Points 
Prayagraj (Allahabad) is situated at $25.45^{\circ} \mathrm{N} 81.84^{\circ} \mathrm{E}$ in the southern part of Uttar Pradesh at an elevation of 98 metres $(322 \mathrm{ft})$ and stands at the confluence of two rivers, the Ganges and Yamuna. The study covers the urban area as well as the adjoining areas of Allahabad district along with industrial areas. In Allahabad, after an initial survey of waste water bodies were selected as sampling sites from the trans-Ganges/Yamuna regions where E. crassipes was present. Waste water bodies without E. crassipes served as control sampling sites present on trans-Ganges region of Allahabad. The present study also examine the changes occurred in fresh aquatic E. crassipes plants surviving under oxidative stress by estimating the enzymatic kinetic constants and the biochemical parameters in roots and shoots of E. crassipes growing in the polluted aquatic environment of Allahabad city region.

The sample collection and experimental analysis was done from three sampling sites of trans-Ganges/Yamuna areas.

The experimental work was performed at the Department of Biochemistry and Biochemical Engineering, SHUATS, Prayagraj (Allahabad) and at the Department of Biochemistry of Allahabad University, Prayagraj (Allahabad).

\section{- Sample Collection:}

The free floating E. crassipes (Fig. 1) plants were collected from the sampling sites for further biochemical estimation. The samples were labelled, stored in clean and dry polyethylene bags and transported to the laboratory. The plants were washed in running tap water blotted dry with filter paper. Damage to root and leaf apices were avoided. The samples were refrigerated at $4^{\circ} \mathrm{C}$ until used.

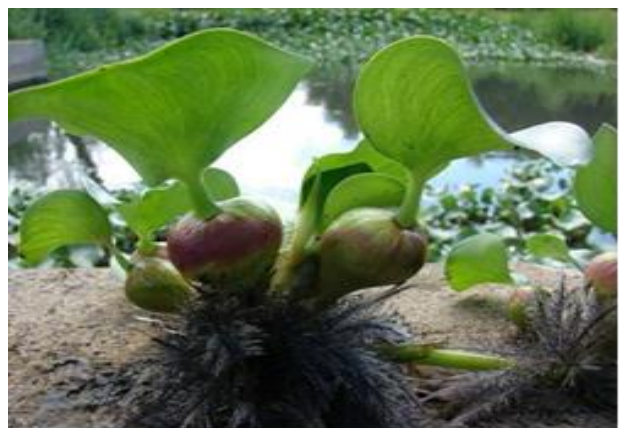

Fig. 1. Image of water hyacinth (E.crassipe)

\section{- Methodology:}

All assays were carried out at room temperature $\left(25-30{ }^{\circ} \mathrm{C}\right)$. The method followed for enzyme extraction was given by [9].Enzyme extraction was carried out at between $4-6^{\circ} \mathrm{C}$. The extracts were prepared by grinding the plant sample $(5.0 \mathrm{~g}$ fresh wt) in $10 \mathrm{ml} 0.1 \mathrm{M}$ phosphate buffer $\mathrm{pH} 7$. The extracts were centrifuged at $15,000 \mathrm{~g}$ for $30 \mathrm{~min}$ at $4^{0} \mathrm{C}$ in refrigerated centrifuge and the supernatant used for enzyme analysis.

Experiments were conducted to determine the effect of substrate concentration on the enzymatic activity of roots and shoots of E. Crassipes. $\mathrm{K}_{\mathrm{m}}$ and $\mathrm{V}_{\max }$ value for each enzyme was calculated using the Lineweaver and Burk (1/V vs $\left.1 /[\mathrm{S}]\right)$ plot.

Catalase (CAT): The enzyme assay was done at five concentrations of $\mathrm{H}_{2} \mathrm{O}_{2}$ substrate ranging from $0.2 \mathrm{mM}$ to $0.8 \mathrm{mM}$ according to the method described by [10].

Guaiacol peroxidase (POD): $\mathrm{K}_{\mathrm{m}}$ and $\mathrm{V}_{\max }$ for POD was done according to the method given by [11]. The enzyme activity was assayed at five concentrations of guaiacol ranging from $0.07 \mathrm{mM}$ to $0.3 \mathrm{mM}$.

Polyphenol peroxidase (PPO): $K_{m}$ and $V_{\max }$ for PPO was done according to the method given by [12]. The enzyme activity was assayed at five concentrations of catechol substrate ranging from $1.7 \times 10^{-3} \mathrm{M}$ to $8.3 \times 10^{-3} \mathrm{M}$. Estimation of Protein [13].

Statistical Analysis: Each treatment was analyzed with a minimum of 3 replicates and the Standard Deviation (SD) was calculated. All the data reported as MEAN \pm SD (Minimum of 3 replicates).

\section{RESULTS}

Lineweaver and Burk (1/V vs $1 /[\mathrm{S}])$ plot was used to determine the kinetic constants Km and Vmax of enzymes (catalase, guaiacol peroxidase and polyphenol oxidase) in crude extracts of roots and shoots of the sampling sites were S1 (Purani Jhusi), S2 (Daragunj), S3 (Nasirpur), S5 (Chheonki), S6 (Maheva) and S7 (Naini Gaon) present in trans-Ganges/Yamuna sites of Prayagraj. The units for $\mathrm{Km}$ and Vmax are mM and Umg-1min-1, respectively. 
- $\quad$ Catalase $\left(V_{\max }\right.$ and $\left.K_{m}\right)(1.11 .1 .6)$ :

Table 1: $\mathrm{K}_{\mathrm{m}}$ and $\mathrm{V}_{\max }$ of catalase in crude extracts of $E$. crassipes.

\begin{tabular}{|l|l|l|l|l|}
\hline \multirow{2}{*}{ Kinetic constants* } & \multicolumn{2}{|l|}{ Trans-Ganges } & \multicolumn{2}{l|}{ Trans- Yamuna } \\
\cline { 2 - 5 } & SHOOTS & ROOTS & SHOOTS & ROOTS \\
\hline $\boldsymbol{K}_{\boldsymbol{m}}(\mathbf{m M})$ & $0.213 \pm 10$ & $0.469 \pm 80$ & $0.274 \pm 22$ & $8.659 \pm 72$ \\
\hline $\boldsymbol{V}_{\max }(\boldsymbol{\mu m o l} / \mathbf{m i n})$ & $30.22 \pm 0.94$ & $66.9 \pm 4.5$ & $41.2 \pm 1.06$ & $85.85 \pm 4.37$ \\
\hline
\end{tabular}

*All values given are MEAN $\pm S D$ of three replicates
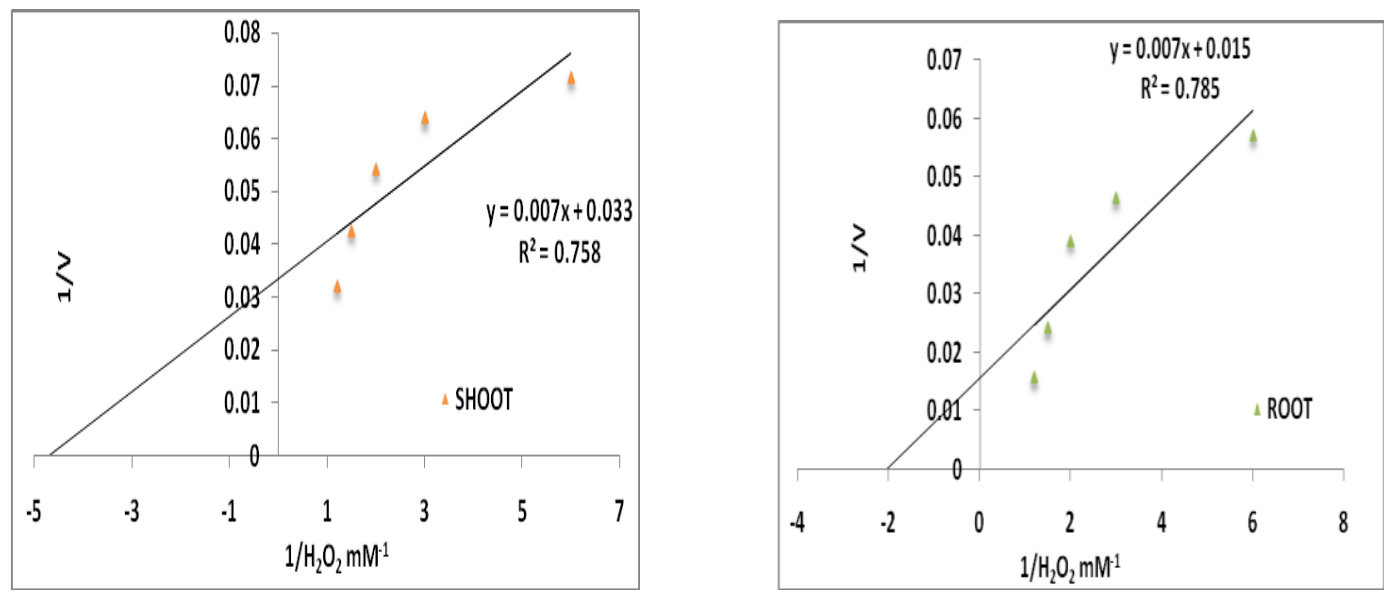

Fig.2: Lineweaver-Burk plot of catalase in crude extracts of E. crassipes (shoots and roots) from Trans-Ganges sites.
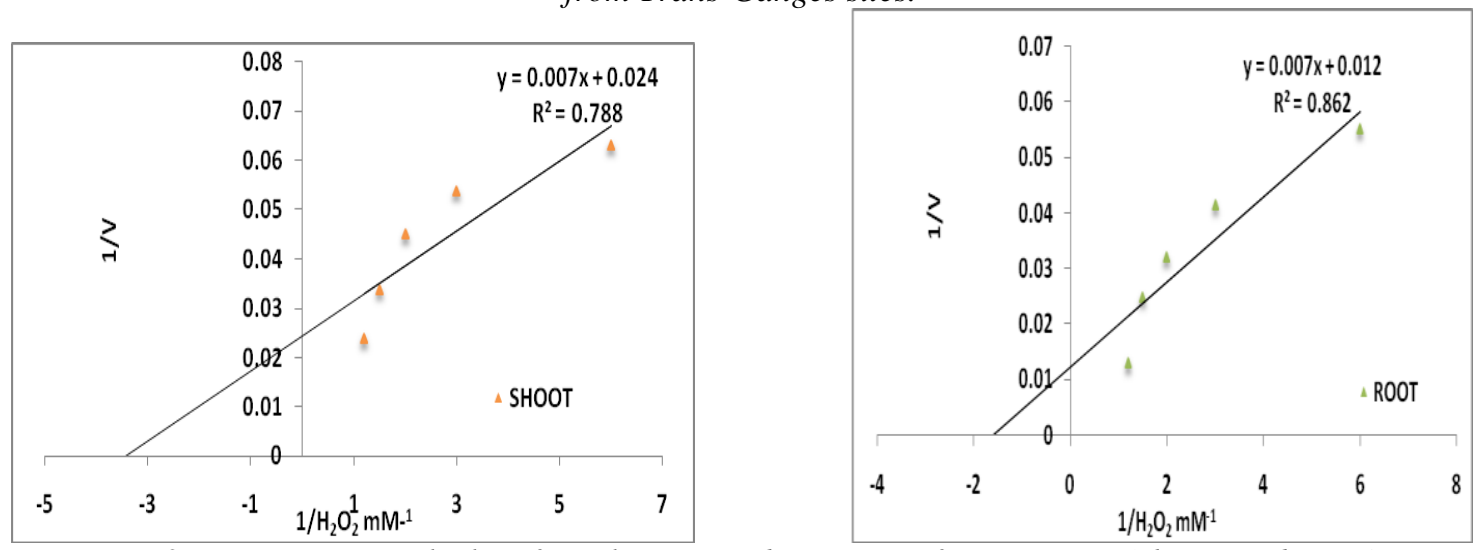

Fig.3: Lineweaver-Burk plot of catalase in crude extracts of E. crassipes (shoots and roots)

From Trans-Yamuna sites.

- $\quad$ Guaiacol peroxidase $\left(V_{\max }\right.$ and $\left.K_{m}\right)(1.11 .1 .7)$ :

Table 2: $K_{m}$ and $V_{\max }$ of guaiacol peroxidase in crude extracts of E. crassipes.

\begin{tabular}{|l|l|l|l|l|}
\hline Kinetic constant* & \multicolumn{2}{|l|}{ Trans-Ganges } & \multicolumn{2}{l|}{ Trans- Yamuna } \\
\cline { 2 - 5 } & SHOOTS & ROOTS & SHOOTS & ROOTS \\
\hline$K_{\boldsymbol{m}}(\mathbf{m M})$ & $0.188 \pm 0.02$ & $0.107 \pm 0.014$ & $0.086 \pm 0.01$ & $0.161 \pm 0.027$ \\
& & & & \\
\hline
\end{tabular}




\begin{tabular}{|l|l|l|l|l|}
\hline $\boldsymbol{V}_{\text {max }}(\boldsymbol{\mu m o l} / \mathrm{min})$ & $6.6 \pm 0.46$ & $24.5 \pm 0.50$ & $2.76 \pm 0.045$ & $43.7 \pm 1.8$ \\
\hline
\end{tabular}

*All values given are MEAN \pm SD of three replicates
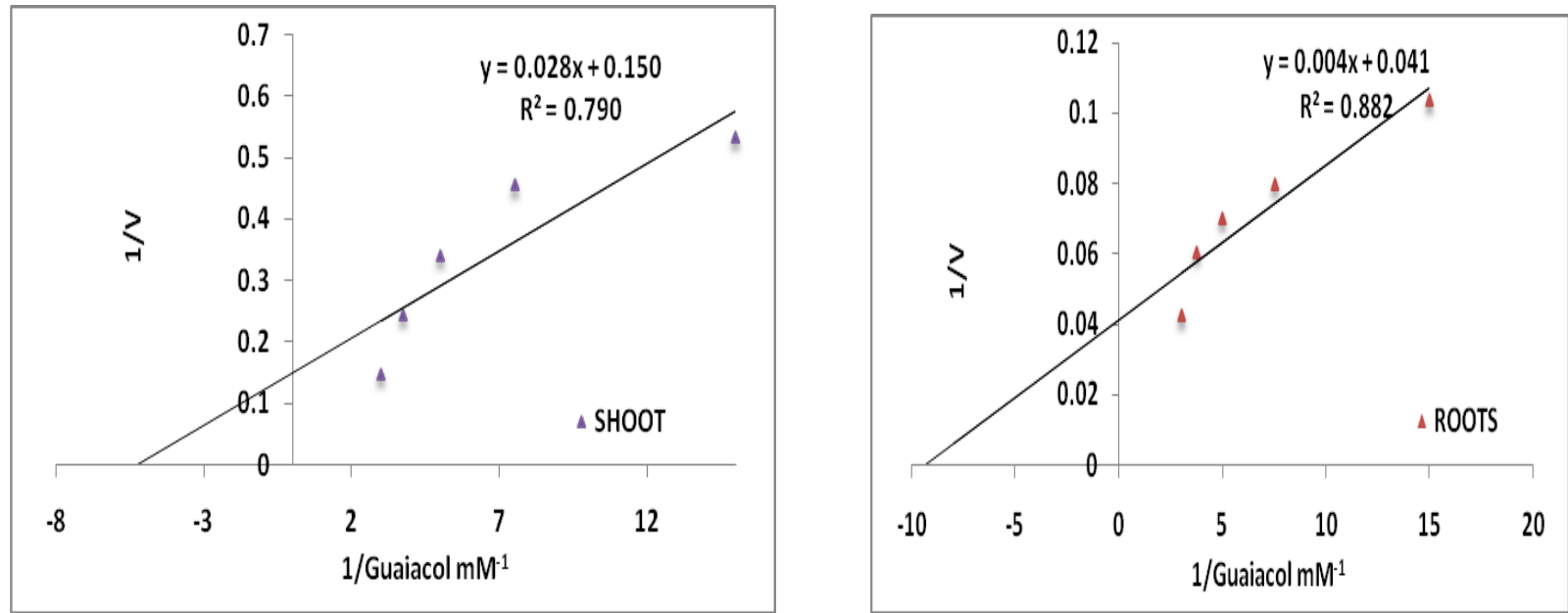

Fig.4: Lineweaver-Burk plot of guaiacol peroxidase in crude extracts of E. crassipes (shoots and roots) from Trans-Ganges sites of Prayagraj.
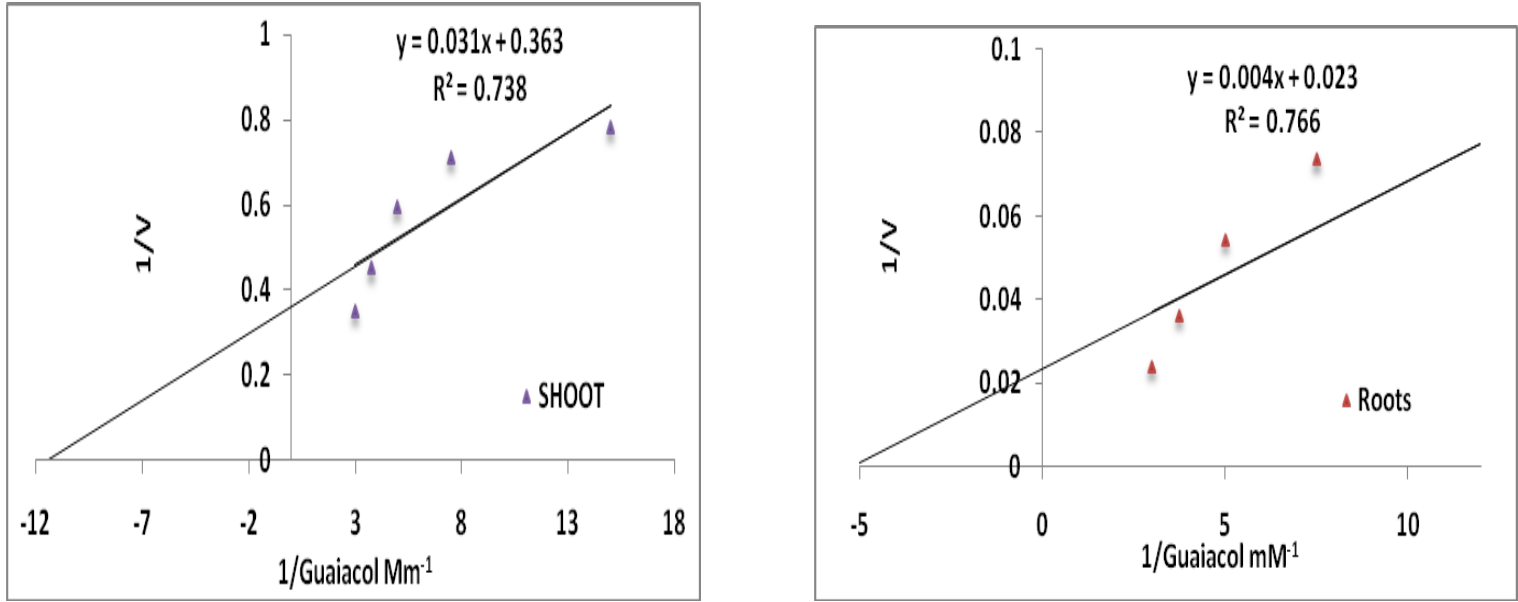

Fig.5: Lineweaver-Burk plot of guaiacol peroxidase in crude extracts of E. crassipes (shoots and roots) from Trans-Yamuna sites of Prayagraj.

- $\quad$ Polyphenol oxidase $\left(V_{\max }\right.$ and $\left.K_{m}\right)(1.14 .18 .1)$ :

Table 3: $K_{m}$ and $V_{\max }$ of poly phenol oxidase in crude extracts of E. crassipes.

\begin{tabular}{|l|l|l|l|l|}
\hline Kinetic constants* & \multicolumn{2}{|l|}{ Trans-Ganges } & \multicolumn{2}{l|}{ Trans- Yamuna } \\
\cline { 2 - 5 } & SHOOTS & ROOTS & SHOOTS & ROOTS \\
\hline $\boldsymbol{K}_{\boldsymbol{m}}(\mathbf{m M})$ & $2.31 \pm 0.9$ & $2.4 \pm 0.2$ & $5.9 \pm 0.2$ & $6.73 \pm 0.7$ \\
\hline $\boldsymbol{V}_{\text {max }}(\boldsymbol{\mu m o l} / \mathbf{m i n})$ & $0.015 \pm 0.004$ & $0.017 \pm 0.003$ & $0.034 \pm 0.001$ & $0.075 \pm 0.004$ \\
\hline
\end{tabular}

*All values given are $M E A N \pm S D$ of three replicates. 

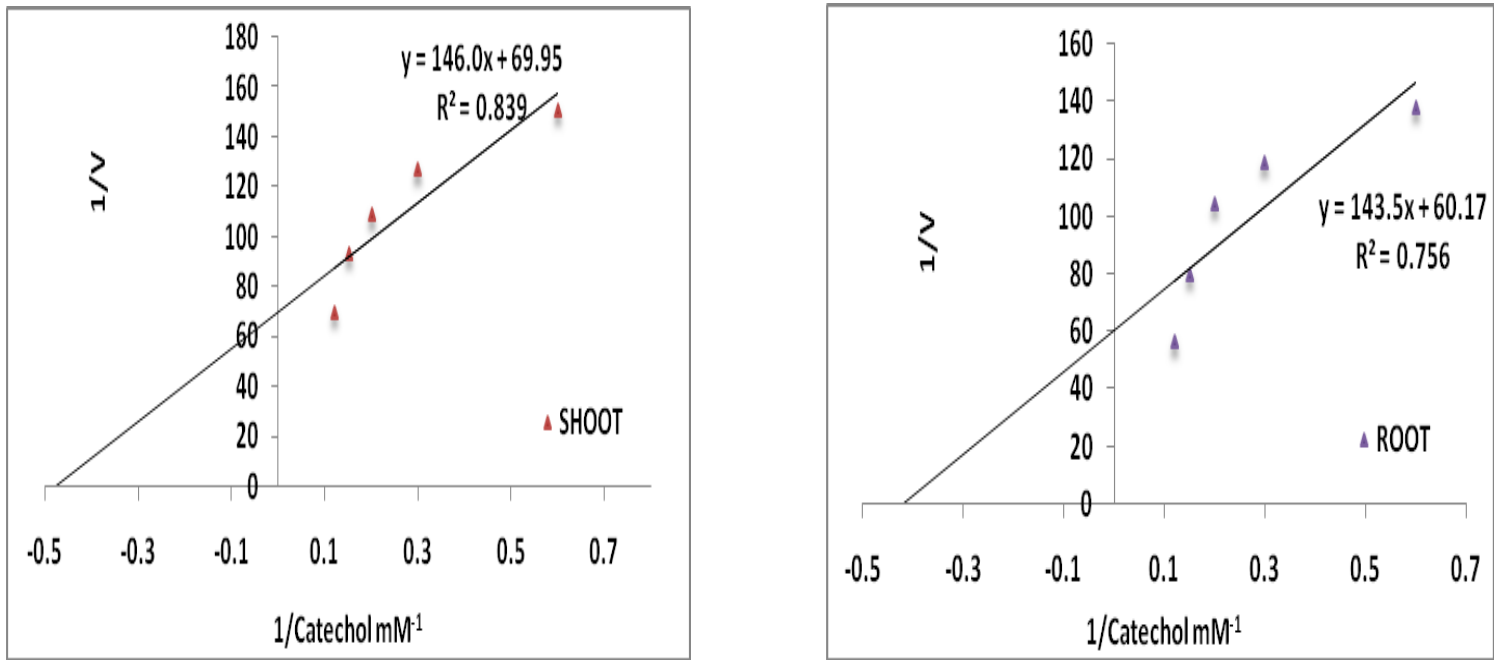

Fig.6: Lineweaver-Burk plot of polyphenol oxidase in crude extracts of E. crassipes

from Trans-Ganges sites of Prayagraj.
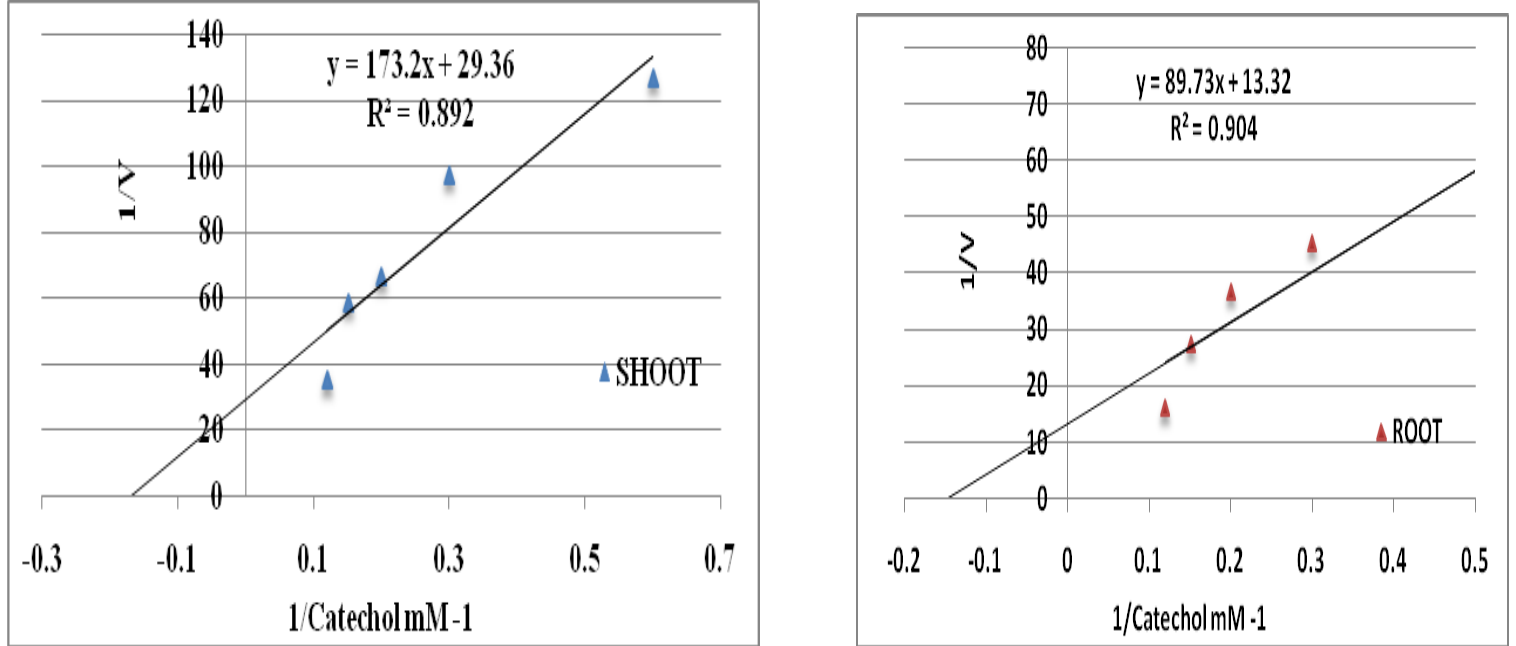

Fig.7: Lineweaver-Burk plot of polyphenol oxidase in crude extracts of E. crassipes from Trans-Ganges sites of Prayagraj.

An increase in the antioxidants activity is often believed to indirectly refle on increase in reactive oxygen species formation due to the environmental stresses appears to be directly or indirectly. From the study in Prayagraj, $\mathrm{K}_{\mathrm{m}}(\mathrm{mM})$ of crude extract of shoots of E. crassipes from trans-Ganges sites were in order of PPO $(2.31 \pm 0.9)>$ CAT $(0.213 \pm 0.01)>$ GPX $(0.188$ \pm 0.02). Similarly, the pattern of increase was observed in $\mathrm{K}_{\mathrm{m}}(\mathrm{mM})$ of roots of E.crassipes from trans-Ganges sites i.e., PPO $(2.4 \pm 0.2)>\operatorname{CAT}(0.469 \pm 0.08)>\operatorname{GPX}\left(0.107 \pm 0.014\right.$. The $\mathrm{V}_{\max }\left(\mathrm{Umg}^{-1} \mathrm{~min}^{-1}\right)$ of crude extract of shoots of E. crassipes were in order of CAT $(30.22 \pm 0.94)>\operatorname{GPX}(6.6 \pm 0.46)>\mathrm{PPO}(0.015 \pm 0.004)$, while the pattern of increase was observed in $\mathrm{V}_{\max }$ $\left(\mathrm{Umg}^{-1} \mathrm{~min}^{-1}\right)$ in crude extract roots of E. crassipes i.e., CAT (66.9 $\pm 4.5>\mathrm{GPX}(24.5 \pm 0.50)>\mathrm{PPO}(0.017 \pm 0.003)$ from transGanges sites.

The pattern of the order in trans-Yamuna sampling sites of $\mathrm{K}_{\mathrm{m}}(\mathrm{mM})$ was observed as PPO $(5.9 \pm 0.2>$ CAT $(0.274 \pm 0.022)>$ GPX $(0.086 \pm 0.01)$ in shoots of E. crassipes while, in roots $\mathrm{K}_{\mathrm{m}}(\mathrm{mM})$ order was PPO $(6.73 \pm 0.7)>$ CAT $(0.659 \pm 0.072)>$ GPX $(0.161 \pm 0.027)$ from trans-Yamuna sites. Similarly, the pattern of the order of $\mathrm{V}_{\max }\left(\mathrm{Umg}^{-1} \mathrm{~min}^{-1}\right)$ observed was as CAT
$(41.2$
$\pm$
1.06)>
GPX
(2.76
$\pm$
$0.045)>$
PPO 
$(0.034 \pm 0.001)$ in shoots of E. crassipes and in crude extracts of roots of E. crassipes the $\mathrm{V}_{\max }\left(\mathrm{Umg}^{-1} \mathrm{~min}^{-1}\right)$ order was CAT $(85.85 \pm 4.37)>$ GPX $(43.7 \pm 1.8)>$ PPO $(0.75 \pm 0.004)$ from trans-Yamuna sites.

From the overall results, it was concluded that the pattern of $\mathrm{V}_{\max }$ shows the increasing order as $\mathbf{C A T}>\mathbf{G P X}>\mathbf{P P O}$; the order for $\mathrm{K}_{\mathrm{m}}$ was as $\mathbf{P P O}>\mathbf{C A T}>\mathbf{G P X}$ observed in both the shoots and roots of E. crassipes present in trans-Ganges/Yamuna sites of Prayagraj. The kinetic constants $\left(\mathrm{V}_{\max }\right.$ and $\left.\mathrm{K}_{\mathrm{m}}\right)$ of enzymes in roots from trans-Yamuna sites were higher than in shoots of E. crassipes in comparison to the trans-Ganges sampling sites. $\mathrm{K}_{\mathrm{m}}$ is an approximate measure of the affinity of the substrate for the enzyme. Large $\mathrm{K}_{\mathrm{m}}$ value represents low affinity of substrate for enzyme and high $\mathrm{K}_{\mathrm{m}}$ value is indicative of high affinity for enzymes. The results observed indicates that PPO has maximum $\mathrm{K}_{\mathrm{m}}$ showing low affinity of substrate followed by CAT and GPX in both shoots and roots of E. crassipes from trans-Ganges/Yamuna sites. $\mathrm{V}_{\max }$ is the maximum velocity at which the enzyme catalysed a reaction and all its active sites is saturated with substrate. $\mathrm{V}_{\max }$ for CAT was reported to be maximum followed by GPX and PPO in E. crassipes present in trans-Ganges/Yamuna sites of Prayagraj.

Further work with partially/purified enzymes are required to substantively contribute towards understanding the detailed mechanism of induced oxidative stress in the E. crassipes.

However, a few reports on kinetic data of plants growing in aquatic eco-systems are available The present study is in agreement with the study done by [14] who stated that for CAT, the $\mathrm{K}_{\mathrm{m}}$ and $\mathrm{V}_{\max }$ treated samples were $0.72 \mathrm{mM}, 0.33 \mathrm{mM} /$ min. mg protein, respectively over the control sample. [15] study reported that the CAT $\mathrm{V}_{\max }$ and $\mathrm{K}_{\mathrm{m}}$ of cabbage leaf was 31.12 $\mu \mathrm{Mmin}^{-1}$ and $25 \mathrm{mM}$, respectively. In the study of [16] on the effect of crude oil on the lentil shoots the kinetic parameters of the CAT, the $\mathrm{K}_{\mathrm{m}}$ and $\mathrm{V}_{\max }$ for the control and treated samples were $1.7 \mathrm{mM}, 0.64 \mathrm{mMmin}^{-1} \mathrm{mg}^{-1}$ protein, and $0.72 \mathrm{mM}, 0.33 \mathrm{mM}$ $\min ^{-1} \cdot \mathrm{mg}^{-1}$ protein, respectively were investigated. [17] reported in his study that the $K_{m}$ and $V_{\max }$ values of PPO for mulberry leaf and mushroom were $35 \mathrm{mM}$ and $3 \mathrm{Uml}^{-1}$, and, $20 \mathrm{mM}$ and $5 \mathrm{Uml}^{-1}$, respectively. Polyphenol oxidase activity (PPO) was extensively studied in jackfruit for its role in enzymatic browning. PPO and the phenolic compound play a vital role in defensive mechanism against pest and diseases. For the studies in jack fruit waste, PPO was purified and characterized and its kinetic constant for PPO was found to be $15.82 \mathrm{mM}\left(\mathrm{K}_{\mathrm{m}}\right)$ and $2182 \mathrm{Uml}^{-1} \mathrm{~min}^{-1}\left(\mathrm{~V}_{\max }\right)$ using catechol as substrate [18].

In study of [19], which had reported that $\mathrm{K}_{\mathrm{m}}$ value of $1.48 \mathrm{mM}$ for $M$. indica kernel peroxidase using pyrogallol as substrate and a $\mathrm{V}_{\max }$ of 0.29 enzyme units/g kernel. Similar research study by various authors on kinetic parameters for horseradish peroxidase calculated from Lineweaver-Burk plots gave a $\mathrm{K}_{\mathrm{m}}$ of $0.8 \mathrm{mM}$ using pyrogallol as substrate [20]; a $\mathrm{K}_{\mathrm{m}}$ of $8 \times 10^{-5}$ and $\mathrm{V}_{\max }$ of 1.53 when hydroquinone was used as substrate [21]. [22] Reported a $\mathrm{K}_{\mathrm{m}}$ of $58 \mu \mathrm{M}$ and $\mathrm{V}_{\max }$ of 3.36 units $/ \mathrm{nmol}$ for french bean peroxidase using pyrogallol as substrate. [23] also reported a $K_{m}$ of $10.50 \mathrm{mM}$ and a $V_{\max }$ of $28.50 \mathrm{nmol} \mathrm{min}^{-1} \mathrm{mg}^{-}$ ${ }^{1}$ as kinetic parameters detected for guaiacol-dependent peroxidase activity in Crocus sativus. Hence, the affinity of peroxidase for its substrate could be directly related to the available hydroxyl groups in the substrate.

The study of [24], reported that based on their linear regression analysis (Lineweaver-Burk plot) over the substrate concentration range of $0.05 \times 10^{-3} \mathrm{M}$ to $0.5 \times 10^{-3} \mathrm{M}$ the $\mathrm{K}_{\mathrm{m}}$ and $\mathrm{V}_{\max }$ of the three plant peroxidases (for $\mathrm{H}_{2} \mathrm{O}_{2}$ in presence of Odianisidine) were: $0.250 \mathrm{mM}$ and $9.09 \mathrm{uM} \mathrm{min}^{-1}$ (tobacco peroxidase), $0.370 \mathrm{mM}$ and $11.11 \mathrm{uM} \mathrm{min}{ }^{-1}$ (cabbage peroxidase) and $0.277 \mathrm{mM}$ and $10.02 \mathrm{uM} \mathrm{min}^{-1}$ (radish peroxidase) respectively. Kinetic studies revealed that Tobacco peroxidase (sourceN. tabaccum) had lower apparent $\mathrm{K}_{\mathrm{m}}$ values and it has more peroxidases than the other two plant peroxidases examined. [25]; [26]; [27] study determined the kinetics factors of the enzyme revealed that $K_{m}$ of the enzyme in the treated sample was much lesser than that of the control, which suggested that affinity of CAT became much higher for its substrate. This result proposed that the plant moved to deal with oxidative stress due to the presence of crude oil.-polluted soil. It has been shown that some stressful environmental factors such as heavy metals and organic pollutants could affect the CAT activity. Catalase dismutates $\mathrm{H}_{2} \mathrm{O}_{2}$ into $\mathrm{H}_{2} \mathrm{O}$ and $\mathrm{O}_{2}$, which is found in peroxisomes, cytosol and mitochondria [28]. POX decomposes $\mathrm{H}_{2} \mathrm{O}_{2}$ by oxidation of co-substrates such as phenolic compounds and antioxidants.

Polyphenol oxidases catalyses both the hydroxylation of monophenols and oxidation of o-diphenols to o-quinones. The $\mathrm{V}_{\max }$ value for PPO had the highest affinity for catechol and catechol was the most efficient phenolic substrate for the plants [29]. PPO is located in the thylakoid membrane of chloroplasts and their phenolic substrates are located in the vacuoles in higher plants In stress condition, the free radical species (forms of active oxygen) are increased, which enhances the activities of these detoxifying enzymes [30]. In the systems involving enzyme, substrate, and metal ion, the metal may react with the substrate, the protein-active groups of enzymes, as well as the enzymesubstrate complex. Information is available on enzyme kinetics ( $\mathrm{V}_{\max }$ and $\mathrm{K}_{\mathrm{m}}$ values) in the presence of heavy metals. The $\mathrm{V}_{\max }$ and $\mathrm{K}_{\mathrm{m}}$ values represent the maximum reaction velocity and the affinity of the enzyme for the substrate, respectively. 


\section{CONCLUSION AND FUTURE SCOPE}

Summarizing the overall finding of the study, it has been concluded that E. crassipes has the ability of improving the physicochemical factors of water along with the accumulating and removal capacity of the toxic metal substances from sampling sites. E. crassipes reduced the properties of toxic metal stress by increasing the antioxidant enzyme activities and shows the effective changes in biochemical parameters and kinetic constants of enzymes in shoots/roots of E. crassipes present in stressed environment for its better survival in contaminated water bodies at both the trans-Ganges/Yamuna sites of Prayagraj. This study determines that $E$. crassipes retains all the characteristics of an aquatic plant for use in phytoremediation of wastewater bodies by removing heavy metal contents and improving physicochemical characteristics of the

\section{ACKNOWLEDGEMENT:}

The present study has been carried out in the Dept. of Biochemistry of SHUATS and university of Allahabad.

\section{REFERENCES}

[1] Postel, S., and Richter, B. (2003). Rivers for Life: Managing Water for People and Nature, (220)., Island Press, Washington, D. C.

[2] Melissa Denchak, (2018). Water Pollution: Everything You Need to Know.

[3] Chu J., Chen J., Wang C., Fu P. (2004). Wastewater reuse potential analysis: implications for China's water resource management. Water Research, 38, pp.2746-2756.

[4] Flathman P. E., Lanza G. R. (1998). Phytoremediation: current views on an emerging green technology. Journal of Soil Contamination, 7, pp. $415-432$.

[5] Prasad M. N. V., Freitas H. (2003). Metal hyperaccumulation in plants-biodiversity prospecting for phytoremediation technology. Electronic Journal of Biotechnology, 6, pp. 285-321.

[6] Reed S. C., Crites R. W. and Middlebrooks E. J. (1995). Natural Systems for Waste Management and Treatment - 2nd ed. McGraw Hill, New York, pp. 173-284.

[7] Grodowitz M. J. (1998). An active approach to the use of insect biology control for the management of Non-Native Aquatic Plants. J. Aquatic plant Manage., 36, pp. $57-61$.

[8] Home Back (2004). Water Hyacinths - A problem Aquatic plants in the Western USA. The western Aquatic Plant Mange. Soc., pp.5.

[9] De Biasi, M.G., S. Astolfi, A. Acampora, S. Zuchi, V. Fonzo, E. Satangelo, R. Caccia, M. Badiani \& G.P. Soressi. 2003. A H2O2-forming peroxidase rather than a $\mathrm{NAD}(\mathrm{P}) \mathrm{H}$-dependent $\mathrm{O} 2$ - synthase may be the major player in cell death responses controlled by the pto-Fen complex following fenthion treatment. Funct. Plant Biol. 30: 409-417.

[10] Matsumura, T., Tabayashi N., Kamagata Y., Souma C. and Saruyama H. (2002). Wheat catalase expressed in transgenic rice can improve tolerance against low temperature stress. Physiol. Plant., 116, pp. 317-327.

[11] Chance B. and Maehly A. C. (1955). Assay of catalase and peroxidase. In: Colowic, S.P.and N.O. Kaplan (Eds.). Methods of Enzymology, Academic Press, New York, USA, 2, pp. 764.

[12] Esterbauer H., Schwarql E., Hayn (1977). A rapid assay of catechol oxidase and laccase using 2-nitro-thiobenjoic acid, Anal. Biochem., 77, 486494.

[13] Lowry, O.H., Rosebrough, N.J., Farr, A.L., and Randall, R.J. (1951) J.Biol.Chem 193: 265 (The original method).

[14] Minai-Tehrani D, Tavakoli Temah A, Rashidfarokhi A, Noormohammadi A, Khodakarami A, Talebi M. (2012). The effect of light crude oilcontaminated soil on the growth and germination of Sorghum bicolor. In: Dobránszki J (Ed) Sorghum. The European Journal of Plant Science and Biotechnology 6 (Special Issue 1), 81-84.

[15] Gholamhoseinian, A., H. Fallah, F. Sharifi-Far and M. Mirtajaddini, 2008. Alpha mannosidase inhibitory effect of some Iranian plant extracts. Int. J. Pharmacol., 4: 460-465.

[16] Sutay (2003). Isolation, characterization and immobilization of polyphenol oxidases from mulberry (morus alba) leaf tissues.

[17] Geetha Rani Y. (2013). Studies on kinetic parameters and biochemical characteristics of polyphenol oxidase purified from jackfruit (artocarpus heterophyllus) waste.

[18] Ebiloma U.G., Arobgba and Aminu O.R. (2011).Some activities of peroxidase from Mango (Mangifera indica L.Var. Mapulehu) Kernel. Int. J. of Biological Chemistry. 5(3), pp.200-206.

[19] Yamaguchi B.M., Cormier M.J. and Dowson J.Y. (2004). Peroxidase isozymes from Horseradish roots. Isolation and physical properties. J. Chem., 10, pp. 6179-6186.

[20] Shukla S.P., Modi K., Ghosh P. K., and Devi S. (2004). Immobilization of horseradish peroxidase by entrapment in natural polysaccharide. J. Applied Polym. Sci., 91, pp.2063-2071.

[21] Yu, J., K.E. Taylor, H. Zou, N. Biswas and J.K. Bewtra, 1994. Phenol conversion and dimeric intermediates in horseradish peroxidase-catalyzed phenol removal from water. J. Environ. Sci. Technol., 28: 2154-2160.

[22] L. Ghamsari, Ezzatollah Keyhani, Shokoofeh Golkhoo (2007). Kinetics Properties of Guaiacol Peroxidase Activity in Crocus sativus L. Corm during Rooting.

[23] Ila Bania and Rita Mahanta (2012). Evaluation of peroxidases from various plant sources. International Journal of Scientific and Research Publications, Volume 2, Issue 5, May 20121 ISSN 2250-3153.

[24] Attar F, Khavari-Nejad S, Keyhani J, Keyhani, E. (2009). Structural and functional alterations of CAT induced by acriflavine, a compound causing apoptosis and necrosis. Annals of the New York Academy of Science 1171: 292-299.

[25] Cheeseman J. M. (2007). Hydrogen peroxide and plant stress: A challenging relationship. Plant Stress 1, 4-15. 
[26] Bolwell G. P. (1999). Role of active oxygen species and NO in plant defense responses. Current Opinion in Plant Biology 2, $287-294$.

[27] Marques A. P. G. C., Rangel A. O. S. S., Castro P.M.L. (2009). Remediation of heavy metal contaminated soils: Phytoremediation as a potentially promising clean-up technology. Critical Reviews in Environmental Science and Technology, 39, pp.622-654.

[28] Blikhina O. Virolainen E., Fagerstedt K.V. (2003). Antioxidants, oxidative damage and oxygen deprivation stress. A review. Ann. Bot. 91:179194.

[29] Geetha Rani Y., Arulvel R., Selvarajan E. (2014). Studies on kinetic parameters and biochemical characteristics of polyphenol oxidase purified from Jackfruit (ARTOCARPUS HETEROPHYLLUS) waste. Int J Pharm Pharm Sci, Vol 6, Issue 9, 473-478.

[31] Zhang Y, Qi H, Taylor R, Xu W, Liu LF, Jin S. (2007) The role of autophagy in mitochondria maintenance: characterization of mitochondrial functions in autophagy-deficient S. cerevisiae strains. Autophagy, 3(4):337-46. 